\title{
THE EDUCATIONAL VALUE OF KAIZEN QUALITY MANAGEMENT
}

\author{
Azhar Arsyad ${ }^{1}$, Nur Aliyah Nur², Nurhikmah ${ }^{3}$, Sophia Azhar ${ }^{4}$ \\ 1,3Institut Parahikma Indonesia, 2,4UIN Alauddin Makassar \\ 1,3Jalan Mustafa daeng Bunga No. 191, Paccinongang, Gowa, \\ 2,4Jalan H.M. Yasin Limpo No. 36, Samata-Gowa \\ Email: azhararsyd@gmail.com ${ }^{1}$, nuraliyahnur@uin-alauddin.ac.id ${ }^{2}$, hikmahnur620@gmail.com ${ }^{3}$, \\ sophiaazhar36@gmail.com ${ }^{4}$
}

\begin{abstract}
:
This paper discusses the educational values of Kaizen culture in Japan. The research used to pose a main question of what educational values Kaizen management and culture has in common, based on the theory proposed by Richard T Kinner, Jerry L. Kernes, and Therese M. Dautheribes which declares that universality and education can coexist within the human community because there is a universal moral education written on the human heart. Since this is a library research and that of observational field of studies with qualitative data the researchers analyzed the research observation results conducted in Toyota, Tokyo, Nagoya, Kyoto, and Osaka as the primary sources of this study by using keywords of Kaizen values, Total Management Quality (TQM), and Kaizen Management Quality (KMQ) then the researchers analyzed and described the information about the educational values found in those primary sources. The results indicated that the universal and educational significant values which Kaizen has in general are discipline, good order (organization), honesty, trust, communication, peaceful life and nonviolent value, neatness, equanimity, and habit formation. Those kind of values will result in benevolence and compassion. In the end, Despite the fact that Kaizen seems to be related to the total quality management studies, this research paves the way to learn more about the importance of moral education in raising one's values via the examples rendered by Kaizen of Japan.
\end{abstract}

\begin{abstract}
Abstrak:
Artikel ini membahas tentang nilai-nilai pendidikan budaya Kaizen di Jepang. Penelitian ini digunakan untuk mengajukan pertanyaan utama tentang apa kesamaan nilai-nilai pendidikan manajemen dan budaya Kaizen, berdasarkan teori yang dikemukakan oleh Richard $\mathrm{T}$ Kinner, Jerry L. Kernes, dan Therese M. Dautheribes yang menyatakan bahwa universalitas dan pendidikan dapat hidup berdampingan dalam komunitas manusia karena ada pendidikan moral universal yang tertulis di hati manusia. Jenis penelitian ini merupakan penelitian Pustaka kualitatif dengan menggunakan hasil observasi penelitian yang dilaksanakan di kota Toyota, Nagoya, Kyoto dan Osaka sebagai sumber utama data penelitian dengan menggunakan kata kunci: nilai-nilai Kaizen, Kualitas Manajemen Total, dan Kualitas Manajemen Kaizen. Hasil penelitian menunjukkan bahwa nilai-nilai penting universal dan pendidikan yang dimiliki Kaizen secara umum adalah disiplin, ketertiban (organisasi), kejujuran, kepercayaan, komunikasi, kehidupan damai dan nilai non-kekerasan, kerapian, keseimbangan batin, dan pembentukan kebiasaan. Nilai-nilai semacam itu akan menghasilkan kebajikan dan kasih sayang. Pada akhirnya, Terlepas dari kenyataan bahwa Kaizen tampaknya terkait dengan studi manajemen kualitas total, penelitian ini membuka jalan untuk mempelajari lebih lanjut tentang pentingnya pendidikan moral dalam meningkatkan nilai-nilai seseorang melalui contoh-contoh yang diberikan oleh Kaizen dari Jepang.
\end{abstract}




\section{Keywords:}

Kaizen, Value, Equanimity, Violence, Neatness

How to Cite: Arsyad, A., Nur, N. A., Nurhikmah, \& Azhar, S. (2021). The Educational Value of Kaizen Quality Management. Lentera Pendidikan :Jurnal Ilmu Tarbiyah dan Keguruan, 24(1), 131-143. https://doi.org/10.24252/lp.2021v24n1i13.

\section{INTRODUCTION}

In terms of religious studies, "primordial tradition" is a very famous term asserted by Huston Smith, the remarkable scholar of religious studies. Griffin in Gallagher believes that the term refers to the universal spiritual education example (Gallagher, 2008). Smith stated that even though the religions have many differences among them, the spiritual principles remain the same. Similarly, Richard T. Kinnier, Jerry L. Kernes, and Therese M. Dautheribes in Cottone, Tarvydas, \& Hartley (2021) argue that in human community, the universality will always coexist. Toward that goal, the people build the universal values for them. Those universal values are the most accepted values which can be discovered in Kaizen and enlist as the reference prototypes or general guidance.

Similarly Kaizen Quality Management (KQM) results in values which tend to be very universal culturally and educationally. There are some related researches that have been conducted that studied about Quality Management in general and Kaizen Quality Management in particular. Mundiri (2017) carried out a study about "Organizational Culture Base on Total Quality Management in Islamic Educational Institution" that revealed that promoting moral quality in the Islamic institutions can be done by conducting unique planning, quality control, improvement, and continuous quality improvement in order to achieve the customer satisfaction based on the standardized or required conformance. In this case, the spiritual depth and moral grandeur are the practical implications of the moral quality. Combining and integrating the new values can be a better behavior and attitude management to face new challenges in the organizational culture in Islamic education institutions. The total quality management can be best adapted from Kaizen Quality Management.

The concept of Kaizen, which emphasizes continual, steady development rather than major changes, provides a solid platform for connecting the core concepts of strategic planning and evaluation. When instructors, students, administrators, and staff work together to recognize and improve all aspects of the learning process, for example, assessment of student learning appears to be most successful. Such data acquired through a rigorous assessment method can and should be used in departmental and institutional strategic planning. Gradual adjustments should be made to the curriculum's content and organization, as well as the courses themselves. Because of the impact on the department's students, relations with other academic and administrative units must inevitably be addressed; coordination with people both inside and outside the department is essential. Slowly but steadily, the institutional culture shifts toward a focus 
on improved approaches to optimize student learning (Khayum, 2017).

Suárez-Barraza \& Rodríguez-González (2015) give empirical evidence of how Kaizen's continuous improvement cycle (PDCA) allows students who have taken the subject of OM in a business school to get better achievements. The findings in each phase of the cycle demonstrate Kaizen-oriented improvement efforts as well as the outcomes in final grades (exams) and written reports. Finally, the study adds to the little literature on Kaizen in education and disseminates this information in order to provide motivation, direction, and support for improving the quality of teaching in a business school.

In addition, Saleem, Khan, Hameed, \& Abbas (2012) conducted the analysis to examine the relationship between Total Quality Management (TQM) and Kaizen who revealed that TQM focuses on improving quality in order to increase customer satisfaction. Kaizen, on the other hand, is a bottom-up method that focuses on modest incremental improvements and is both top-down and bottom-up. When compared to Kaizen, TQM is more expensive to implement. Improvements are created using the resources available to the organization through kaizen. For efficient kaizen implementation, the organization's culture must be supportive, and the results of continuous improvement should be disseminated to the entire organization for employee motivation and the success of the continuous improvement program. Furthermore, Kregel (2019) asserted that Kaizen could successfully improve course quality, especially in the first two years of newly developed courses.

Based on those previous research results, Kaizen is used in the discussion about quality management in many aspects such as education, while this research specifically reveals the detail of educational values in Kaizen that can be practically adapted into the education, curriculum, and policy making in an institution. It is further discussed in the part of results and discussion of this article.

\section{RESEARCH METHOD}

Since this is a library research and that of observational field of studies with qualitative data, it would begin with identifying sources that deal with Kaizen practice in Japan. Observation has been done in Toyota city in particular and in other cities such as Tokyo, Nagoya, Kyoto, and Osaka in general in 2018. The final step is writing a paper based on the findings during the research under the theme of the Universal values of education. Therefore, the researchers analyzed the research observation results conducted in Toyota, Tokyo, Nagoya, Kyoto, and Osaka as the primary sources of this study by using keywords of Kaizen values, Total Management Quality (TQM), and Kaizen Management Quality (KMQ) then the researchers analyzed and described the information about the educational values found in those primary sources.

\section{RESULTS AND DISCUSSION}

\section{From "The North Wind" to "The Sun"}

Tim Clark explained that after Hideyoshi pacified Japan, the samurai changed drastically (Clark, 2014). Their position as skilled fighters faded, and became more 
concerned with spiritual growth, teaching, and the arts rather than martial training with civil society at peace. He continued stating that they had grown into what Hideyoshi had dreamed nearly three centuries earlier by 1867, when the public wearing of swords was banned and the warrior class was abolished (Clark, 2014).

As a matter of fact, from the historical and factual point of view, none will argue that there was a change in attitude of the authorities in Japan from force value of Bushido which is the value of the North Wind- despite the exposition of Japanese thought written by Inazo Nitobe, Ph.D in his book - to tranquility, education, management and peaceful value which is the value of "the Sun". As we can see later, Bushido then represents "force" and Kaizen represents "the shining sun".

Historically speaking, after World War II in which Hiroshima and Nagasaki were bombed as the result of "force" value, to aid in the reconstruction of Japanese industry, American occupation forces brought in American experts, while the Civil Communications Section (CCS) established a Management Training Program that included statistical control methods as part of the overall material. Homer Sarasohn and Charles Protzman developed and taught this course in 1949-50. Sarasohn suggested W. Edwards Deming for more Statistical Methods preparation. The Economic and Scientific Section (ESS) were also charged with developing Japanese management skills, and Edgar McVoy was instrumental in taking Lowell Mellen to Japan in 1951 to better implement the TWI programs. Prior to Mellen's arrival in 1951, the ESS community had a training film called "Improvement in 4 Steps" that introduced the three TWI "J" programs (Work Instruction, Job Methods, and Job Relations), (Kaizen eno Yon Dankai). As a result, "Kaizen" was first introduced to Japan.

In 1960, the Emperor of Japan awarded Dr. Deming the 2nd Order Medal of the Sacred Treasure for his pioneering, introduction, and implementation of Kaizen in Japan. As a result, the Union of Japanese Science and Engineering (JUSE) founded the Deming Prizes, which are awarded annually for achievements in product quality and dependability. Florida Power \& Light Co. (FPL) received the Deming Prize on October 18, 1989 , for its outstanding achievements in process and quality control management. FPL was the first company to receive the Deming Prize outside of Japan (US National Archives, n.d.).

\section{The Original Meaning of Kaizen}

The Sino-Japanese word "kaizen" simply means "good change", neither of which has any intrinsic significance of "continuous" nor "philosophy" in dictionaries or in daily use in Japan. In the same way as the English word Debundked in Janjić, Bogićević, \& Krstić (2019) believed that "improvement" applies to a one-time or continuous improvement, major or small, the term "improvement" refers to any improvement. However, provided Japan's custom of marking industrial or business improvement techniques with the term "kaizen" (due to a lack of a particular Japanese word with a specific meaning "continuous improvement" or "philosophy of improvement"). In English, the word Kaizen is usually applied to initiatives for implementing quality 
improvement, or even taken to mean a "Japanese philosophy" thereof, particularly in the case of oft-emulated practices spearheaded by Toyota. The following article focuses on certain meanings of the word as they are commonly used in contemporary management discussions.

Kaizen is a regular process with a goal that goes beyond simply increasing efficiency. It's also a mechanism that, when done properly, humanizes the workplace and avoids excessively difficult work ("muri"), and teaches people how to use the scientific method to conduct research on their own work as well as how to identify and remove waste in business processes. Overall, Tozawa in (Tapping \& Shuker, 2018) argued that the procedure demonstrates a more humane approach to staff and productivity: "The idea is to nurture the company's human resources as much as it is top raise and encourage participation in kaizen activities". As Hall in Protzman, Whiton, Kerpchar, Lewandowski, Stenberg, \& Grounds (2018) assumed that Implementation success necessitates "the participation of workers in the improvement". Kaizen involves employees at all levels of an organization, from the CEO to the janitorial staff, as well as external partners when necessary. Kaizen may take the form of an entity, a recommendation system, a small group, or a large group. It typically includes a small group of people improving their own work environment and competitiveness within a work station or local area at Toyota. A line supervisor often leads this community through the kaizen process; in some cases, this is the line supervisor's primary responsibility. Kaizen in industries on a broad, cross-departmental scale creates complete quality control and frees human efforts by increasing efficiency by the use of machines and computing capacity.

While kaizen (for example, at Toyota) typically yields small improvements, the culture of aligned small improvements and standardization yields large results in the form of compound productivity improvement. This ideology varies from the midtwentieth-century "command and control" improvement programs. Making adjustments, tracking performance, and modifying are all part of the Kaizen technique. Smaller experiments, which can be quickly modified as new improvements are proposed, are replacing large-scale pre-planning and intensive project scheduling. It is now known as a week plan, Hamel in (Berhe, 2021) argued that it is intended to fix a specific problem over the course of a week which refers to the term "kaizen blitz" or "kaizen event". These are restricted in nature, and any problems that occur are usually addressed in subsequent blitzes. According to Wikipedia, the title of "Zenkai" is given to anyone who makes a significant contribution to the effective implementation of kaizen during kaizen events.

\section{The Five "S" of Kaizen Educational Value}

The five primary "S" values explain how to arrange a work space for productivity and effectiveness by recognizing and storing commonly used objects, maintaining the area and items, and maintaining the new order. Takashi in (Pittman, 2012) found that the decision-making process normally starts with a discussion about standardization, which 
helps people understand how they can do their jobs. The brief explanations of each value process can be helpful in comprehending them on the following.

\section{Sorting (Seiri)}

Eliminate all unnecessary tools and parts. Go through all tools, materials, and so forth in the plant and work area. Keep only essential items and eliminate what is not required, prioritizing things per requirements and keeping them in easily-accessible places. Everything else is stored or discarded.

\section{Straightening or Setting in Order to Streamline or Flow (Seiton)}

Organizing the job, personnel, equipment, components, and orders such that work flows waste-free by value-added activities with the necessary division of labor to meet demand. It is by far the most misunderstood and misapplied $\mathrm{S}$, and it is the reason why so many lean transformations have struggled to produce the expected results. This phase eliminates the majority of non-value-added time when used correctly with a well-defined flow, enabling the rest of the zero-defect concept to be applied. Simply put, you cannot have an organized flow of problems to solve until you have an orderly flow of problems to solve, which is impossible.

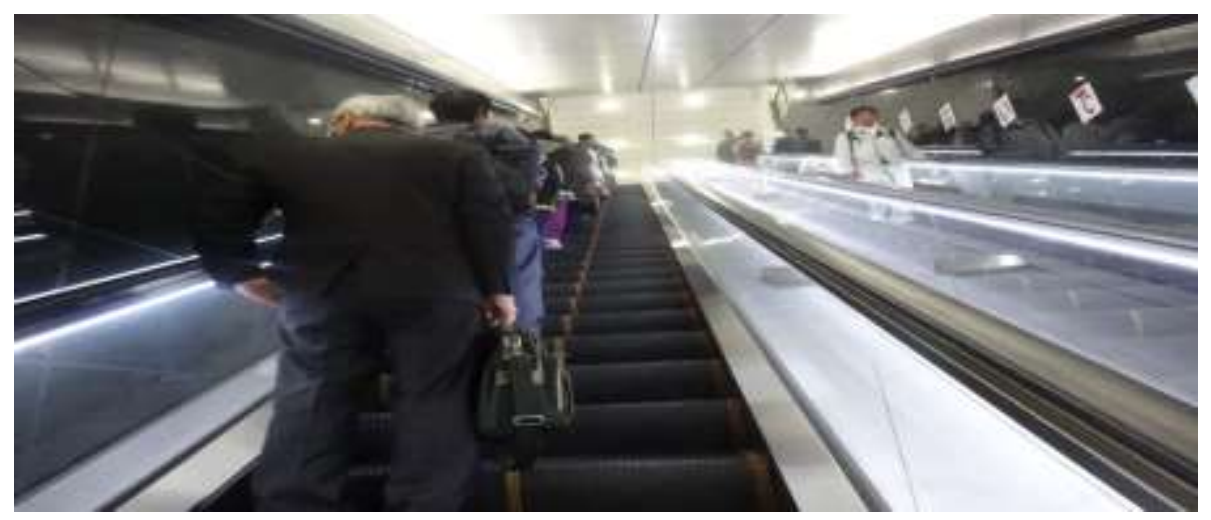

Figure 1. Orderliness or "set in order" value on the escalator of the railway station in Nagoya (on the left row)

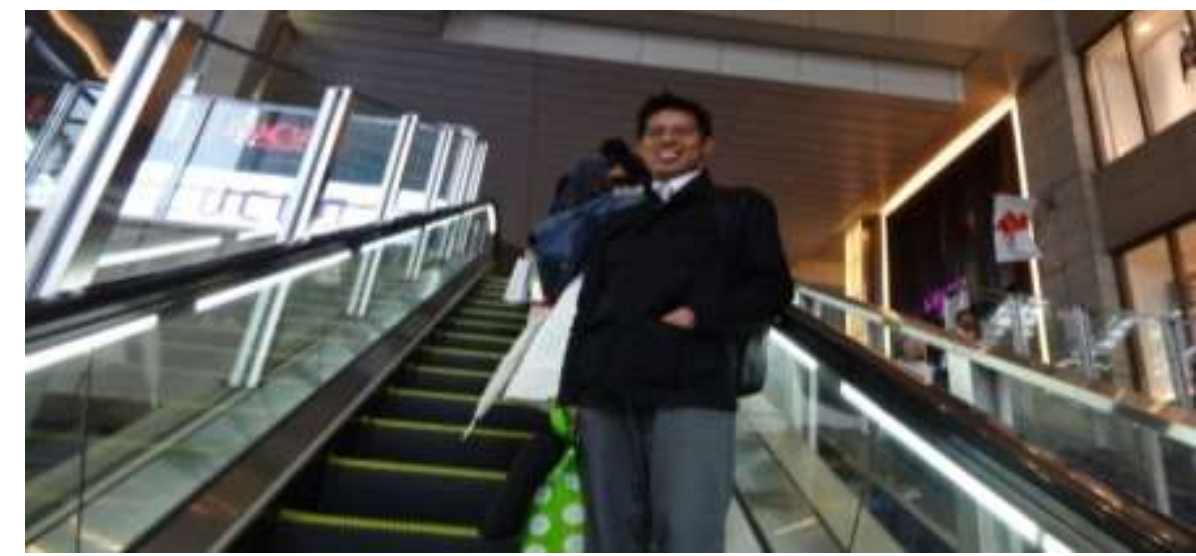

Figure 2. "set in order" value in Osaka 


\section{Shining (Seiso)}

Keep the workspace, as well as all appliances, clean, tidy, and ordered. Clean up the work area at the end of each shift and make sure everything is back in its proper position. This move ensures that the workstation is prepared for the next user and that the workstation is kept in order.

\section{Standardize (Seiketsu)}

To encourage interchangeability, ensure that procedures and setups are consistent in the process.

\section{Sustain (Shitsuke)}

Make it a lifestyle choice. This entails dedication. To avoid backsliding, ensure "disciplined" obedience to the $5 \mathrm{~S}$ rules and procedures. Keeping the expectations high. The discipline of the people and Shinkanzen operator is very well known by all people travelling to Japan.

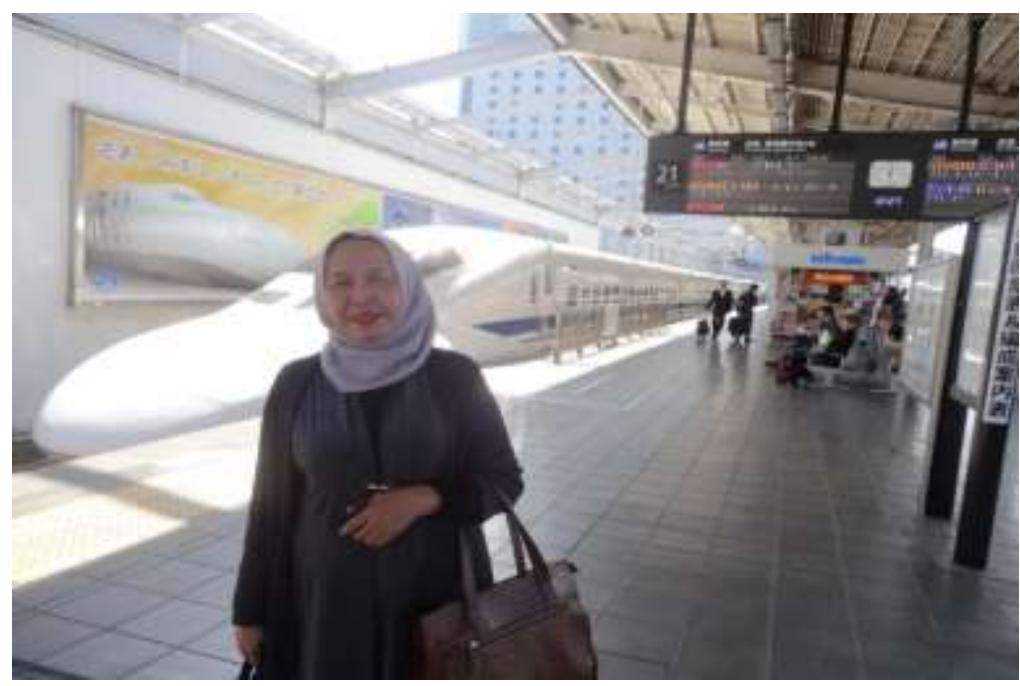

Picture 3. "On time" and "Discipline" value

\section{Additionals}

Health, protection, and satisfaction are three other phases that are often included. This is not, however, a typical sequence of "phases." For example, safety is built into the $5 S$ technique rather than being a separate phase. As a result, the phases have been added to explain the advantages of $5 \mathrm{~S}$ rather than to create a new or more inclusive approach.

\section{Safety}

Often a sixth step, "Security," is added (United States Government, 2012). There is a controversy about whether adding this sixth "S" encourages safety by expressly stating this importance, or whether relegating a robust safety program to a single item in an efficiency-focused business approach undermines it. 


\section{Security}

There is also the option of adding a seventh phase, "Security" Bicheno in (Zokaei, Lovins, Wood, Hines, \&Planning, 2016). The seventh "S" defines and discusses risks to key business categories such as fixed assets, material, human resources, brand equity, intellectual property, information technology, assets-in-transit, and the extended supply chain, allowing protection to be viewed as an investment rather than a cost. The techniques are based on those described in the book Total Security Management (TSM). For a company's entire value chain, total security management, or the corporate method of designing and implementing rigorous risk management and security practices, is used.

As previously mentioned, the Toyota Production System is known for kaizen, in which all line staff are required to interrupt their moving production line in the event of any abnormality and, along with their supervisor, recommend an adjustment to fix the abnormality, thus initiating a kaizen. The kaizen activity cycle can be summarized as follows: standardize an operation and tasks, Calculate the procedure (find cycle time and amount of in-process inventory). Measurements should be compared to the specifications. Improve production by innovating to meet requirements. Ensure that the latest, enhanced operations are consistent.

Aside from business implementations, Anthony Robbins and Robert Maurer in (Taylor, 2020) made Kaizen principles have become well-known as personal development principles. Maurer examines how individuals can use a kaizen approach in both their personal and professional lives in his book One Small Step Can Change Your Life: The Kaizen Way and CD set The Kaizen Way to Success (Maurer, 2014). Liker and Meier address the kaizen blitz and kaizen burst (or kaizen event) approaches to quality improvement in the Toyota Way Field book. A kaizen blitz, also known as rapid development, is a concentrated effort to enhance a specific process or operation. The basic idea is to locate and eliminate waste as soon as possible. Another method is to use a kaizen burst, Liker \& Meier in Protzman, Whiton, Kerpchar, Lewandowski, Stenberg, \& Grounds (2018) which is a single kaizen operation focused on a single process in the value stream.

Kaizen, as many authorities hold, has something to do with Lean educational management, which is a long-term approach to work that consistently aims to achieve small, gradual improvements in processes in order to increase performance and quality, and an approach to running an enterprise that follows the principle of continuous improvement. It has a system which is called Kaizen teian -- (Kaizen (改善: means "improvement" and "Teian" (提案 means "proposal") -- a proposal structure in the Japanese style for continuous improvement -- which is the most straightforward and reliable way to channel employees' creative energy and practical knowledge that brings into perfect focus the management, guidance, and growth of kaizen-Teian systems.

Kaizen-Teian ("Improvement Proposal") has the following features: 1. Workforcedriven, incremental, long-term improvement process, 2. Empowers employees who are more involved in the process and promotes organizational solidarity, 3. Take advantage 
of the knowledge of those who are most familiar with the operation, 4. Less obstructive, 5. Only the "local optimum," not the "national optimum," can be achieved by the workforce, and 6. It can be difficult to include anyone in the company because the process being changed is fundamentally "flawed."

Characterizing kaizen as simply "continuous improvement" as Peter Keen, Chairman of Keen Innovations, gave food for thought, the idea is trivialized, and it is portrayed as cautious and lacking in creativity. In most cases, kaizen represents a radical dedication to an entire way of working that necessitates a floor-to-ceiling shift in management, work, manager-worker relationships, discipline, decision-making, and information organization, transforming an organization into a federation of problem solvers.

Therefore, when implemented, there should be at least 6 Characteristics of KaizenTeian to be recalled: 1 . Accumulating minor changes over time, 2. Involving the entire workforce by focusing on a team of collaborators (rather than a team of experts/consultants), 3. Encouraging continued improvement (vs. lack of continuity), 4. Applying gradual changes in small increments (vs. big leaps), 5. Establishing a fundamental component of a lean organization (Identifying waste in operations is the other building block.), and in addition 6. Making typical scenario: a small group of 8-20 individuals from all levels and functions/departments of the company that identifies, analyzes, and implements a project in 4-5 days Chang et. al in (Marin-Garcia, JuarezTarraga, \& Santandreu-Mascarell 2018).

Furthermore, Kaizen is related to "Muda Elimination". In Japanese, the word "muda" means "waste". Any operation that does not add value is considered a waste of time "muda". It applies to other tools as well, such as machines and materials. The removal of muda could be the most cost-effective way to boost efficiency and lower costs. Rather than increasing expenditure, Imai in (Simmons, 2018) argued that Kaizen emphasizes the removal of muda in the "gemba" (field) in the hope of adding value".

It has to be admitted furthermore that in the following contents of this section, many of the next paragraphs that I wish to arrange are picked up here and there from Wikipedia, the free encyclopedia and other references. I also have to acknowledge that the footnotes are also cited from those I encountered in it, except those which will not be the same as the ones I am holding while I was in Japan and with a small change. By doing this. It will then make it easy for me to finish my job to explore the values of Kaizen.

\section{Kaizen Application in Other Fields}

Despite this, Kaizen, which means "improvement" or "change for the better" in Japanese, refers to a theory or set of practices that focuses on continuous process improvement in manufacturing, engineering, and business management. Healthcare Julie in (Daft, 2013), psychotherapy (Feldma, 1992), life coaching, government, banking, education (Simanjuntak, 2015), and other industries have all used it. Imai in Janjić, Bogićević, \& Krstić (2019) argued that Kaizen refers to operations that continuously develop all roles and include all staff, from the CEO to assembly line personnel, when 
used in the corporate sense and extended to the workplace. It also refers to processes that cross organizational boundaries into the supply chain, such as buying and logistics.

In addition, Kaizen seeks to reduce waste by enhancing organized practices and procedures (see lean manufacturing). After WWII, Kaizen was first introduced in a number of Japanese companies, inspired in part by American business and quality management teachers who visited the country. Since then, it has spread all over the world Michael in (Sanden, 2020) and it is now being used in settings other than business and productivity.

\section{Kaizen Benefits}

Prabhat Pandey, one of the Mechanical Engineers working at BHL wrote that among Kaizen advantages are incremental changes that add up to significant gains. They lead to increased efficiency, quality, and protection, as well as faster delivery, lower prices, and higher customer satisfaction. In addition to these business advantages, Kaizen-based companies' workers typically find jobs to be simpler and more enjoyable, resulting in higher employee morale and job satisfaction, as well as lower turnover. Employee skills, waiting times, transportation, worker motion, overproduction, excess inventory, efficiency, and processes are all places where Kaizen reduces waste. Besides, product quality, capital efficiency, production capability, communications, space use, and employee retention are all the Kaizen benefits.

In addition to the above benefits, Pandey also mentioned that Kaizen is a process that produces instant results. Instead of focusing on large-scale, capital-intensive upgrades, Kaizen emphasizes innovative investments that address a large number of small problems over time. The capital projects phase would also benefit from Kaizen, but the true power of Kaizen lies in the ongoing process of making incremental changes that enhance processes and minimize waste. By engaging workers, they begin to consider how to adjust their environment in order to improve outcomes in their workplace. Employee morale improves as work becomes more fun and straightforward.

Kaizen additionally includes every employee in the process of transition, which is often done in small, gradual steps. It focuses on finding and fixing problems at their roots, as well as modifying standards to ensure that the problem is permanently solved. It's not uncommon for Kaizen to generate 25 to 30 suggestions per employee per year, with over $90 \%$ of those being implemented. Toyota, for example, is well-known as a pioneer in the use of Kaizen. In 1999, 7,000 Toyota workers in one U.S. plant submitted over 75,000 proposals, with 99 percent of them being adopted (Pandey \& Pandey, 2014).

Finally, talking about Kaizen, one should not get rid of ideas and terms like "Business process reengineering", "Mottainai, a sense of regret concerning waste", "Muda", "Overall equipment effectiveness", "Root cause analysis", "Scrum, an agile methodology for managing software projects", "Six Sigma", "Statistical process control", "Theory of Constraints", "Total productive maintenance" ,"The principle of creative problem solving is known as TRIZ", "Kaikaku", "Kanban", "Visual Control", "Learning-bydoing", and "Quality circle", and "Management fad" (Dinero, 2019). 
All those terms are very related to the value of 5S (seiri “整理”(sorting) resembling the value of "Niat" in "bahasa Indonesia" or sorting any other things in the heart other than the goal of the mentioned heart testimony (commitment), seiton “整頓”(setting in order) resembling the value of “discipline”, seiso “清掃” (shining) resembling the value of cleanning, seiketsu “清潔” (standardize) resembling "purifying” in the value of fasting for the sake of character building, and shitsuke “㷣” (sustain) resembling the value of loyalty.

\section{CONCLUSION}

Unlike Bushido which used to be "Samurai" oriented, Kaizen educational values lie economically practiced for the sake of economy and education success. Thus, war in economy and education and not war physically. Thus, Japanese men displayed ageless qualities of manliness by preferring sympathy over confrontation and benevolence over belligerence. No force is needed, let alone "violence".

Due to a lack of physical strength and combat skills, one must rely on wits rather than firearms, on strategy rather than swords. It was unusual samurai, to be sure. After Hideyoshi pacified Japan, the samurai changed drastically. With civil society at peace, the Japanese image as skilled warriors faded, and they became more concerned with spiritual growth, teaching, and the arts, rather than martial training. They had matured into what Hideyoshi had imagined nearly three centuries earlier: sword-less samurai by 1867, when the public wearing of swords was banned and the warrior class was abolished. Moreover, Japan finally was beaten by the USA and surrendered without any condition after Hiroshima and Nagasaki were bombed in 1942. Later, Japan had to take a new lesson that force will take it nowhere. Peaceful ways, discipline, and wits will.

Learning from the history of Kaizen and Bushido as the former backbone values in history, one can conclude that in any society, let alone plural society, "violence" belief or religion for example should not be a symbol of a new reign of thought and rules for everyone. It's a lament that such a kingdom will never be realized. On the other side, whatever one bears up for, calmness, equanimity, and happy mind, as well as tranquility, order, and regularity, will always be a new captain. Surely, history has taught us that brutality gets no one anywhere. The devil is in the details, and the business structure will reign supreme in both management culture and education.

The research resulted in something which was so fascinating. Kaizen proves to have universal significant educational values. i.e., commitment and discipline, good order (organization), cleanliness (in purification of muda and waste), communication, being smart and wise (wits) which are the characters of the soul, peaceful life, and nonviolent value, neatness, equanimity, and actualization of shining soul, honesty and loyalty, trust, communication, peaceful life or nonviolent value, neatness, and habit formation. Those kind of values will result in benevolence and compassion. 


\section{REFERENCES}

Berhe, H. H. (2021). Application of Kaizen philosophy for enhancing manufacturing industries' performance: exploratory study of Ethiopian chemical industries. International Journal of Quality and Reliability Management. https://doi.org/10.1108/IJQRM-09-2020-0328.

Clark, T. (2014). The Bushido Code: The Eight Virtues of the Samurai in Brett \& Kate McKay. The Art of Manliness.

Cottone, R. R., Tarvydas, V. M., \& Hartley, M. T. (2021). Ethics and Decision Making in Counseling and Psychotherapy. In Ethics and Decision Making in Counseling and Psychotherapy. https://doi.org/10.1891/9780826135292.

Daft, R. L. (2013). Organization Theory and Design 11th Edition. South-Western Cengage Learning. $\quad$ https://www.amazon.com/Organization-Theory-Design-RichardDaft/dp/1111221294.

Dinero, D. A. (2019). Training within industry: The foundation of lean. In Training Within Industry: The Foundation of Lean. https://doi.org/10.1201/b18692.

Gallagher, M. P. (2008). Truth and Trust: Pierangelo Sequeri's Theology of Faith. Irish Theological Quarterly, 73(1-2). https://doi.org/10.1177/0021140008091689.

Janjić, V., Bogićević, J., \& Krstić, B. (2019). Kaizen as a global business philosophy for continuous improvement of business performance. Ekonomika, 65(2). https://doi.org/10.5937/ekonomika1902013j.

Khayum, H. (2017). Quality of Higher Education: Implementation of Kaizen Philosophy. World Journal of Social Sciences, 7(1). https://doi.org/10.20944/preprints201608.0107.v1.

Kregel, I. (2019). Kaizen in university teaching: continuous course improvement. International Journal of Lean Six Sigma, 10(4). https://doi.org/10.1108/IJLSS-082018-0090.

Feldma, M. M. (1992). Audit in psychotherapy: the concept of Kaizen. Psychiatric Bulletin. https://doi.org/10.1192/pb.16.6.334.

Marin-Garcia, J. A., Juarez-Tarraga, A., \& Santandreu-Mascarell, C. (2018). Kaizen philosophy: The keys of the permanent suggestion systems analyzed from the workers' perspective. TQM Journal, 30(4). https://doi.org/10.1108/TQM-122017-0176.

Maurer, R. (2014). One Small Step Can Change Your Life: The Kaizen Way. Workman Publishing.

Mundiri, A. (2017). Organizational Culture Base On Total Quality Management In Islamic Educational Institution. ADRI International Journal of Islamic Studies and Social Sciences,

$1(1)$. https://lp3m.unuja.ac.id/unduh_jurnal/143/2017_Mundiri_Organizational\%20C ulture.pdf.

Pandey, M., \& Pandey, P. (2014). Better English for Better Employment Opportunities. International Journal of Multidisciplinary Approach and Studies, 1(4). https://www.researchgate.net/publication/264788119_Better_English_for_Bette r_Employment_Opportunities.

Pittman, J. M. (2012). Improving Performance in Service Organizations: How to 
Implement a Lean Transformation, by Joyce A. Miller, Tatiana Bogatova, and Bruce Carnohan . Administration in Social Work, 36(4). https://doi.org/10.1080/03643107.2012.682030.

Protzman, C., Whiton, F., Kerpchar, J., Lewandowski, C. R., Stenberg, S., \& Grounds, P. (2018). The lean practitioner's field book: Proven, practical, profitable and powerful techniques for making lean really work. In The Lean Practitioner's Field Book: Proven, Practical, Profitable and Powerful Techniques for Making Lean Really Work. https://doi.org/10.4324/9781315373843.

Saleem, M., Khan, N., Hameed, S., \& Abbas Ch, M. (2012). An analysis of relationship between Total quality management and Kaizen. Life Science Journal, 9(3). https://www.semanticscholar.org/paper/An-Analysis-of-Relationship-betweenTotal-Quality-Saleem-Khan/9a2f50384ed29371496bf9270df5ec5324c32d3a.

Sanden, G. R. (2020). The language of global success: how a common tongue transforms multinational organizations. Journal of Multilingual and Multicultural Development, 41(3). https://doi.org/10.1080/01434632.2019.1621111.

Simanjuntak, M. (2015). Penerapan Manajemen Kaizen di Institusi Publik Non Profit. UGM.

Simmons, R. (2018). Gemba Kaizen: A Commonsense Approach to a Continuous Improvement Strategy, 2nd ed. Quality Management Journal, 25(1). https://doi.org/10.1080/10686967.2018.1404374.

Suárez-Barraza, M. F., \& Rodríguez-González, F. G. (2015). Bringing Kaizen to the classroom: lessons learned in an Operations Management course. Total Quality Management and Business Excellence, 26(9-10). https://doi.org/10.1080/14783363.2015.1068594.

Tapping, D., \& Shuker, T. (2018). Value Stream Management for the Lean Office. In Value Stream Management for the Lean Office. https://doi.org/10.1201/b16934.

Taylor, D. (2020). Awaken the giants within. In David Taylor's Inside Track: Provocative Insights into the World of IT in Business. https://doi.org/10.4324/9780080939186-61.

United States Government. (2012). Lean and Environment Training Modules. Green Supply Network.

US National Archives. (n.d.). SCAP collection. PR NewsWire.

Zokaei, K., Lovins, H., Wood, A., Hines, P., Planning, R., Almond, D., Milne, K., Rome, A., Cohen, M., Bicheno, J., Holweg, M., The, I. N., \& Goyena, R. (2016). The Lean Toolbox, 5th edition. A handbook for lean transformation. Lean Games View project Dismantling relational contracting at Nissan View project. In Journal of Chemical Information and Modeling (Vol. 19, Issue December). 